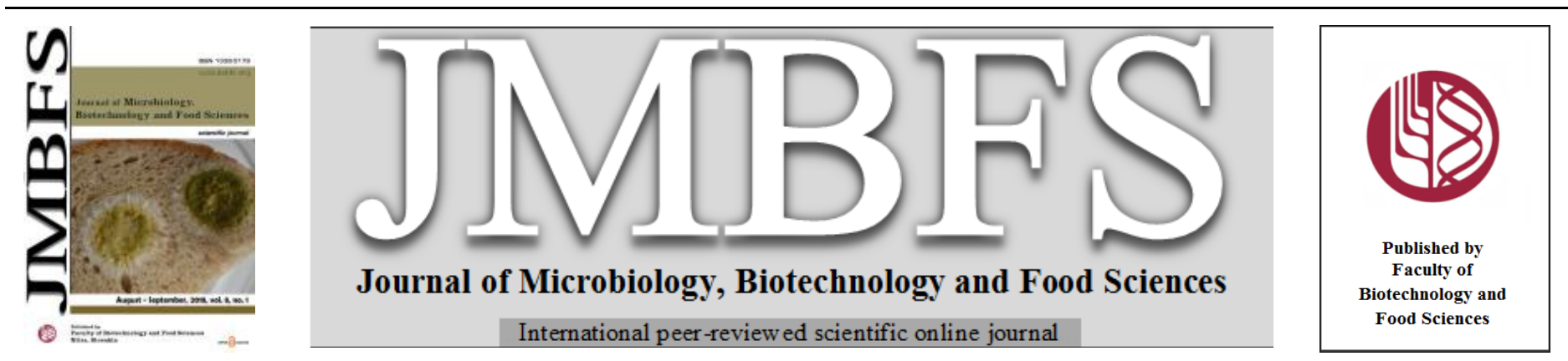

\title{
NARINGINASE: MICROBIAL SOURCES, PRODUCTION AND APPLICATIONS IN FOOD PROCESSING INDUSTRY
}

\author{
Mukesh Yadav ${ }^{l *}$, Nirmala Sehrawat ${ }^{1}$, Anil K. Sharmal, Vikas Kumar ${ }^{1}$, Amit Kumar ${ }^{2}$ \\ Address(es): \\ ${ }^{1}$ Department of Biotechnology, Maharishi Markandeshwar (Deemed to be University), Mullana 133207, Ambala, India, Tel. +91-7404206245 \\ ${ }^{2}$ Department of Biotechnology, College of Natural and Computational Science, Debre Markos University, Ethiopia
}

*Corresponding author: mukeshyadav7@gmail.com

doi: 10.15414/jmbfs.2018.8.1.717-720

\section{ARTICLE INFO}

Received 17. 5. 2018

Revised 22. 6. 2018

Accepted 3. 7. 2018

Published 1. 8. 2018

\section{Review}

OPEN $\partial$ ACCESS

\begin{abstract}
Naringin is a flavonoid naturally present in citrus fruits. It is present in orange, grapefruit, lemon and other fruits of citrus family. Naringin is the major cause of bitterness in citrus fruit juices. This flavonoid may cause interference during the citrus fruit juice processing. Naringinase (E.C.3.2.1.40) is an enzyme which catalyzes the hydrolysis of naringin into prunin and then into naringenin, which is non-bitter and tasteless. Naringinase is produced by many microorganisms but the commercial production of this microbial enzyme is still the area of interest. Naringinase is chiefly produced by various fungal strains and it has been reported for elimination of bitter flavour (due to naringin) in citrus fruit juice. Few bacterial sources have also been reported for naringinase. Besides removal of bitterness, naringainase has potent application in enhancement of aroma in wine making. This review focuses over microbial sources, production and applications of naringinase in food industries.
\end{abstract}

Keywords: Naringin, naringinase, food industry, citrus juice, bitterness

\section{INTRODUCTION}

Enzymes are the functional proteins which catalyzes various chemical reactions. Some fundamental and important characteristics of enzymes make them strong candidate molecules for industrial processes. These characteristics are (i) higher specificity and efficiency, (ii) enzymes can be recovered after the product formation and (iii) enzymes can be produced from rapidly growing microorganisms (Yadav et al., 2014). Enzymes are employed in different areas of industries including food, feed, detergent, textiles, laundry, tanning, as well as pharmaceuticals, cosmetics, and fine-chemicals industries (Miguel et al., 2013). Enzymes found in nature have been used in the production of food products (Kirk et al., 2002). A large number of enzymes have already been commercialized for different industrial processes. Industrial applications account for major share of the global market of enzymes (van Oort, 2010). Food enzymes are the most widely used enzymes at industrial level and represent the major share in enzyme market (Miguel et al., 2013). Food enzymes are commonly used in baking, beverages and brewing, dairy, dietary supplements, as well as fats and oils and also in synthesis of artificial sweeteners (Kirk et al., 2002; Xu et al., 2003; Berka and Cherry, 2006; Binod et al., 2008; Fernandes, 2010; Singh and Yadav, 2012). Continuous developments and advancement in bioprocess technology resulted in considerable and improved yields of enzymes by fermentation (Falch, 1991; Poulsen and Buchholz, 2003; Petersen, 2005; Miguel et al., 2013). Enzyme stability can be increased while specificity can be altered (Falch, 1991; Poulsen and Buchholz, 2003; Petersen, 2005; Miguel et al., 2013). Microbial sources of enzymes are more advantageous than animal or vegetable sources (Soares et al., 2012). The obvious advantages include low production costs, easy large-scale production in industrial fermenter, better possibility of genetic manipulation and fast growth. These characteristics make microbial enzymes more suitable biocatalysts for various industrial applications (Hasan et al., 2006). Nonenzymatic processing and chemical based processing posses some drawbacks. High temperatures and/or high pressures needed to drive reactions lead to high energy costs and may require large volumes of cooling water downstream. High chemicals and energy consumption as well as harmful by-products have a negative impact on the environment. In a number of cases, some or all of these drawbacks can be virtually eliminated by using enzymes. Generally, either the enzymes are used to convert the raw material into the main product, or the enzymes are used as additives to alter a functional characteristic of the product (Miguel et al., 2013). In the first situation, the enzymatic activity can be optimized and controlled as compared to the second situation where it is more difficult to control the enzymatic reaction (Illanes, 2008).

Naringin (4, 5, 7-trihydroxyflavanone 7-rhamnoglucoside), is the major component in grapefruit. It contributes more than the other components to the bitterness of both fresh fruit and juice. Naringinase is an enzyme complex consisting of $\alpha$-L-rhamnosidase (E.C. 3.2.1.40) and flavonoid- $\beta$-glucosidase (E.C. 3.2.1.21) activities. In typical processing, naringinase converts naringin to naringenin in a two step process, the substrate naringin is hydrolyzed by rhamnosidase component of enzyme naringinase to produce prunin which is then converted by flavonoid $\beta$-D-glucosidase to naringenin (Chandler and Nicol, 1975; Habelt and Pittner, 1980). The rhamnosidase activity of naringinase is essential for bitterness removal (Puri et al., 1996). This review focuses over microbial sources of naringinase and potent applications in food industry.

\section{MICROBIAL SOURCES OF NARINGINASE}

Various microbial sources of naringinase have been reported world wide by different researchers. Most of the studies focus over fungal sources. Few reports on bacterial production of naringinase are also available. Among various microbial sources, strains of Aspergillus sp. and Penicillium sp. have been shown to specially endow with naringinase activity. Aspergillus niger has been reported as major source of naringinase. The different microbial sources of naringinase have been listed in Table 1 . 
Table 1 Microbial sources of naringinase

\begin{tabular}{|c|c|}
\hline Source microorganism & Reference(s) \\
\hline Aspergillus foetidus & Mendoza-Cal et al., 2010 \\
\hline Aspergillus niger $\mathrm{HPD}-2$ & Mendoza-Cal et al., 2010 \\
\hline Aspergillus niger & Bram and Solomons, 1965; Mendoza-Cal et al., 2010; Awad et al., 2016 \\
\hline Aspergillus oryzae $\mathrm{SS}$ & Mendoza-Cal et al., 2010 \\
\hline Penicillium caseicolum & Mendoza-Cal et al., 2010 \\
\hline Penicillium chrysogenum NRRL & Mendoza-Cal et al., 2010 \\
\hline Penicillium glaucum & Mendoza-Cal et al., 2010 \\
\hline Penicillium roqueforti I & Mendoza-Cal et al., 2010 \\
\hline Penicillium roqueforti II & Mendoza-Cal et al., 2010 \\
\hline Penicillium roqueforti $\mathrm{CNRZ}$ & Mendoza-Cal et al., 2010 \\
\hline Rhyzopus delemar & Mendoza-Cal et al., 2010 \\
\hline Aspergillus niger MTCC 1344 & Puri et al., 2005 \\
\hline Staphylococcus xylosus MAK2 & Puri et al., 2010a; Puri et al., 2011 \\
\hline Candida tropicalis & Saranya et al., 2009 \\
\hline Penicillium decumbens PTCC 5248 & Nourouzian et al., 2000 \\
\hline Aspergillus flavus & Radhakrishnan et al., 2013 \\
\hline Penicillium purpurogenum & Patil and Dhake, 2014 \\
\hline Aspergillus aculeatus & Manzanares et al., 2001; Anfeng et al., 2015 \\
\hline Aspergillus niger ATCC 1015 & González-Vázquez et al., 2011 \\
\hline Bacillus amyloliquefaciens 11568 & Zhu et al., 2017 \\
\hline
\end{tabular}

\section{PRODUCTION OF MICROBIAL NARINGINASE}

Various microbial sources have been reported for production of naringinase Various media components have been studied to find efficient media formulations to support maximal production of microbial naringinase Thammawat et al. (2008) isolated 348 fungal strains from 128 various host samples, collected from 11 different sources which are capable of hydrolyzing naringin by growing at $28^{\circ} \mathrm{C}$ on selective synthetic minimal medium, with $\mathrm{pH}$ 5.8 , containing $0.1 \%$ naringin. Further all the isolated fungal strains were primary screened by growing the fungi at $40^{\circ} \mathrm{C}$ for 7 days in synthetic minimal medium, $\mathrm{pH} 4.0$, added with $0.1 \%$ naringin and by investigation of the naringin hydrolysis of the fungal culture filtrate, forty fungal isolates were obtained. Secondary screening of selected 40 isolates was done on the basis of both, glycosidase activities, $\alpha$-L-rhamnosidase and $\beta$-D-glucosidase at $40^{\circ} \mathrm{C}, \mathrm{pH} 4.0$, and naringinase activity at the temperatures of 50,55 and $60^{\circ} \mathrm{C}$ and at both $\mathrm{pH} 3.0$ and 4.0. Aspergillus niger BCC 25166 was selected and genetically identified For optimization of the medium and conditions for enzyme production, submerged fermentation was found suitable with inoculums concentration of $10^{5}$ spores/ml in Czapek-Dox medium, $\mathrm{pH} 4.0$, containing $0.1 \%$ naringin. The maximum naringinase production of selected fungal strain (117.77 U/mg protein) was obtained with medium supplemented by $3.75 \mathrm{~g} / 1$ rhamnose as a carbon source and using $2.5 \mathrm{~g} / 1 \mathrm{NaNO}_{3}$ as a nitrogen source. For high production of $\alpha-\mathrm{L}$ rhamnosidase $(303.20 \mathrm{U} / \mathrm{mg}$ protein), $2.5 \mathrm{~g} / \mathrm{l}$ soya peptone should be used instead.

Response surface methodology for optimizing the fermentation medium to enhance naringinase production by Staphylococcus xylosus at shake flask level have been reported by Puri et al. (2010a). Authors have investigated some important factors such as carbon (sucrose), nitrogen (sodium nitrate), $\mathrm{pH}$ and naringin (inducer) that significantly affects naringinase production. In order to determine optimal levels of each factor, 22 full factorial central composite designs were applied. Using this methodology, the authors obtained optimum values for the critical components. These values included, sodium nitrate, $10.0 \%$ sucrose, $10.0 \%$, pH 5.6, biomass concentration, $1.58 \%$, and naringin, $0.50 \%$ $(\mathrm{w} / \mathrm{v})$, respectively. These optimal parameters resulted in experimental naringinase production of $8.45 \mathrm{IU} / \mathrm{mL}$. Similarly, Puri et al. (2011) reported Staphylococcus xylosus MAK2, a soil isolate which was a Gram-positive coccus, a nonpathogenic member of the coagulase-negative Staphylococcus family for production of naringinase in a stirred tank reactor. An initial medium at $\mathrm{pH} 5.5$ and a cultivation temperature of $30^{\circ} \mathrm{C}$ were found to be optimal for enzyme production. They found that addition of $\mathrm{Ca}^{2+}$ caused stimulation of enzyme activity. The effect of various physico-chemical parameters, such as agitation, temperature, $\mathrm{pH}$, and inducer concentration were studied. The enzyme production was found to increase in the optimized medium due to addition of citrus peel powder. A double increase in naringinase production was achieved by using different technological combinations. The process optimization using technological combinations allowed rapid optimization of large number of variables, which significantly improved enzyme production in a 5- 1 reactor in 34 hours. Naringinase production was further increased in the bioreactor (8.9 $\mathrm{IU} / \mathrm{mL})$ by increase in sugar concentration $\left(15 \mathrm{gl}^{-1}\right)$ in the fermentation medium Thus, availability of naringinase renders it attractive for potential biotechnological applications in citrus processing industry.

Mendoza-Cal et al. (2010) also studied the naringinase production by twelve filamentous fungi using agro industrial residues; orange and grapefruit rind as substrates which contain naringin, an important inductor for this enzyme. The percentage of naringin hydrolyzed from grapefruit rind by Aspergillus foetidus, Aspergillus niger and Aspergillus niger HPD-2 was found 81, 80 and 79\% respectively. They observed that temperature, $\mathrm{pH}$ and water activity (Aw) influenced the volumetric and specific naringinase activity of each strain. The optimal culture conditions for A. foetidus, A. niger and A. niger HPD2 were as follows: $\mathrm{pH} 5.4,35^{\circ} \mathrm{C}, 0.5222 \mathrm{Aw}$; $\mathrm{pH} 5.4,35^{\circ} \mathrm{C}, 0.7533 \mathrm{Aw} ; \mathrm{pH} 5.4,40^{\circ} \mathrm{C}$, 0.7533 Aw respectively. A. foetidus showed highest volumetric activity 2.58 $\mathrm{Uml}^{-1}$, when grown on grapefruit rind. Among the strains used, optimal naringinase production was with A. foetidus. The use of grapefruit rind as a substrate gave a higher yield of naringinase production than using orange rind. Aspergillus flavus has also been studied for the production of naringinase (Radhakrishnan et al., 2013). Naringenin was found to be best inducer at the concentration of $0.08 \mathrm{mg} / \mathrm{L}$. Authors also studied the effect of metal ions on naringinase activity. $\mathrm{Mg}^{2+}$ and $\mathrm{Ca}^{2+}$ ions were found important for the better activity of the enzyme naringinase while $\mathrm{Fe}^{2+}$ and $\mathrm{Mn}^{2+}$ have been found to have an inhibitory action on growth and enzyme production. Puri et al. (2005) used Aspergillus niger MTCC 1344 for the production of extracellular naringinase in a medium composed of molasses, yeast extract and salts. Molasses and peptone were found to be most effective for enzyme production among all other carbon and nitrogen sources. The rate of enzyme production was enhanced by addition of metal ions to the fermentation medium.

Media optimization studies have also been reported by Chen et al. (2010) Authors investigated nutrient requirements for extracellular naringinase production by Aspergillus oryzae JMU316. To determine the impact of different carbon and nitrogen sources on naringinase production, one-factor-at-a-time method was used. They observed that naringin exhibited the highest naringinase activity among all other carbon sources. Likewise Pomelo pericarp powder also shows comparable naringinase activity and it was selected as a cheap carbon source as it is a waste of fruit process. Peptone proved to be the most suitable nitrogen source for naringinase production. The concentration of various media constituents including pomelo pericarp powder, peptone, and minerals, orthogonal matrix method was optimized. The optimal concentration of the components were $15 \mathrm{~g}$ pomelo pericarp powder, $12 \mathrm{~g}$ peptone, $0.2 \mathrm{~g} \mathrm{CaCl}_{2}, 0.4 \mathrm{~g}$ $\mathrm{NaCl}, 2 \mathrm{~g} \mathrm{MgSO} \cdot 7 \mathrm{H}_{2} \mathrm{O}$ and $1 \mathrm{~g} \mathrm{~K}_{2} \mathrm{HPO}_{4}$ in $1 \mathrm{~L}$ distilled water for producing 408.28 IU/mL naringinase activity.

Kaur et al. (2010) worked on waste residues generated by citrus fruit processing industry. A recombinant $\alpha$-L-rhamnosidase from Clostridium stercorarium has been found suitable for hydrolysis of naringin which was relatively stable at $60^{\circ} \mathrm{C}$. The enzyme was purified and used for hydrolysis of naringin extracted from citrus peel waste. The results indicated recombinant $\alpha$-L-rhamnosidase as potent industrial enzyme and can be used for producing rhamnose from citrus peel. In other study, Puri et al. (2010b) attached a His-tag to the rhamnosidase gene ramA from Clostridium stercorarium to facilitate its purification from Escherichia coli BL21 (DE3) cells containing the pET-21d/ramA plasmid. The enzyme was purified by single step purification and immobilized in Ca-alginate beads. The optimum $\mathrm{pH}$ levels of the free and immobilized recombinant rhamnosidase were found to be 6.0 and 7.5 , and the optimum temperature 55 and $60^{\circ} \mathrm{C}$ respectively. The free and immobilized enzymes showed $76 \%$ and $67 \%$ hydrolysis of the naringin in Kinnow juice, respectively. Immobilization of recombinant rhamnosidase enabled its reutilization up to 9 hydrolysis batches without an appreciable loss in activity. Zverlov et al. (2000) also reported hydrolysis of naringin to rhamnose and pruning by alpha-L-rhamnosidase of Clostridium stercorarium.

Saranya et al. (2009) demonstrated that naringinase (E.C.3.2.1.40), cleaves naringin into naringenin and release rhamnose and prunin as by-product. They conducted study on naringinase producing yeast Candida tropicalis. Later they purified and characterized the enzyme. The enzyme was purified by using different techniques; ultrafiltration, Ammonium sulfate precipitation, Anion exchange chromatography and Gel filtration chromatography. SDS-PAGE technique was used to check the purity of enzyme and it had been found that the 
molecular weight of the enzyme is 73 and $78 \mathrm{kDa}$. The purified enzyme was characterized to find its substrate concentration, optimum $\mathrm{pH}$ and temperature. The substrate specificity was compared with rutin and naringin.

Pavithra et al. (2012) isolated the four strains of naringin hydrolysing bacteria All the four isolates revealed extracellular naringinase activity. The most efficient strain was selected and identified as Serratia Sp. Effect of various carbon and nitrogen sources was studied at shake-flask level. Glucose positively affected the naringinase production at higher rate among all the carbon sources. Peptone supplemented with ammonium nitrate was found to be favourable. A maximum naringinase activity of $9.2 \mathrm{U} / \mathrm{L}$ was achieved in the medium containing naringin, glucose, peptone, ammonium nitrate and salts. Sahota and Kaur (2015) reported production of nariniginase from mutated yeast Clavispora lusitaniae with the activity of $0.0135 \mathrm{IU} / \mathrm{mL}$. The parameters optimized for naringinase production included $\mathrm{pH}$, temperature, naringin and rhamnose concentration. Authors developed technology for the production of low alcoholic naturally carbonated fermented kinnow beverage with yeast Clavispora lusitaniae. Along with production and application, authors also reported development of a rapid detection test for naringinase producing microorganisms using $\mathrm{FeCl}_{3}$.

\section{POTENT APPLICATIONS OF NARINGINASE IN FOOD INDUSTRY}

Naringin is a flavonoid naturally present in citrus fruits. It is present in oranges, grapefruit, and lemon, these flavonoids may cause interference during the citrus fruit juice processing and cause for the bitter taste (Konno et al., 1982). The processing of citrus fruit juice has faced formidable problems in terms of bitterness and delayed onset of bitterness. The bitterness affects its consumer acceptability (Olsen and Hill, 1964). Two classes of chemical compounds namely flavonoids and limonoids were found responsible for bitterness in citrus juices. The bitterness in grape fruit juice can be decreased by using enzymes such as naringinase which hydrolyzes naringin into relatively non-bitter compounds (Olsen and Hill, 1964). Naringinase (E.C.3.2.1.40) is an enzyme which catalyzes the hydrolysis of naringin into prunin and then into naringenin, which is nonbitter and tasteless. This enzyme has two different enzyme activities (due to two different subunits). One is $\alpha$-L-rhamonosidase (E.C.3.2.1.40) which acts on naringin to release prunin and $\alpha$-L-rhamnose. Second is $\beta$-D-glucosidase (E.C.3.2.1.21) which acts on prunin to release naringenin and $\beta$-D-glucose (Puri and Banerjee, 2000; Puri et al., 2005; Puri and Kalra, 2005; Saranya et al., 2009). Naringinase is produced by many microorganisms but there are only few reports on the commercial production of this enzyme (Puri and Banerjee, 2000 Mendoza-Cal et al., 2010). Use of naringinase for debittering of grapefruit juice has been reported by various research groups. Naringinase produced from fungi (especially Aspergillus niger) has been used for elimination of bitter flavor (due to naringin) in citrus fruit juice (Bram and Solomons 1965; Puri et al., 2005) Immobilized naringinase from Aspergillus niger was used by Olson et al. (1979) for debittering of grapefruit juice. The use of $\alpha$-L-rhamnosidases for debittering of grapefruit juices by hydrolysis of naringin to prunin and L-rhamnose has been observed by many workers (Chen et al., 1990; Yadav and Yadav, 2000; Busto et al., 2007; Puri et al., 2008). Recently, purification and characterization of a naringinase from a newly isolated strain of Bacillus amyloliquefaciens 11568 has been reported by Zhu et al., 2017. The isolated naringinase was capable of hydrolyzing naringin. Authors showed that a concentration of $4 \mathrm{U} / \mathrm{mL}$ of the enzyme in citrus juice was sufficient to remove the naringin. The study provides an in-depth insight into the structure of the naringinase and the hydrolysis of naringin and other flavonoids. Patil and Dhake (2014) also reported application part of naringinase. The citrus juice bitterness was removed to certain extent by addition of partially purified naringinase of Penicillium purpurogenum. Maximum removal of naringin content $(74 \%)$ was achieved at naringinase concentration of $1.0 \mathrm{~g} / \mathrm{L}$, with incubation at $40^{\circ} \mathrm{C}$ for 4 hours.

Rhamnosidases play an important natural role in the modification of the viscous property of gellan gum (Yanai and Sato, 2000; Manzanares et al., 2001; Hashimoto et al., 2003; Puri et al., 2010b). This enzyme has also attracted interest from biotech groups for its role in rhamnose production (Puri and Banerjee, 2000). Rhamnosidase activity of naringainase in combination with $\beta$ glucosidase and arabinosidase has also been considered suitable for aroma enhancement in wine making. The immobilized enzyme has been used to develop a continuous process for wine aroma enhancement (Caldini et al., 1994; Gallego et al., 2001). Naringin and its hydrolysis products, rhamnose, prunin and naringenin have growing interest due to their biological activities (Chen et al., 1990) and as starting material for the synthesis of substances used in pharmaceutics, cosmetic and food technology (Hagedorn \& Kaphammer, 1994).

\section{CONCLUSION AND FUTURE PROSPECTS}

Citrus fruit juice market includes both large scale commercial as well as small scale fresh juice extraction processes. The onset of bitterness in citrus juice is one of the important drawbacks of citrus juice. Naringin is the major factor contributing to the bitterness of citrus fruit juice. Microbial naringinase has been found effective in hydrolyzing the naringin and the resultant products do not contribute bitterness. Microbial naringinase has been studied for removal of citrus juice bitterness. It is a promising enzyme for citrus juice industry.
Moreover, it can be produced by using waste residues (chiefly citrus peel powder) from citrus industries. Besides removal of bitterness from citrus juice, naringinase has found applications in wine industry and also in other food industries. Naringinase mediated treatment of citrus juice may be a better and environmental friendly approach for removal of bitterness. More extensive research is required for use of promising microbial naringinase at commercial level.

Acknowledgement: Authors acknowledge the help and support by Head, Department of Biotechnology, Maharishi Markandeshwar (Deemed to be University), Mullana-Ambala, Haryana, India.

\section{REFERENCES}

Anfeng, X., Hongyan, Y., Changzheng, W., Hui, N., Qiuming, Y., \& Huinong, C. (2015). Immobilization and characterization of naringinase from Aspergillus aculeatus onto magnetic $\mathrm{Fe}_{3} \mathrm{O}_{4}$ nanoparticles. Nanoscience and Nanotechnology Letters. 7, 770-778. https://doi.org/10.1166/nnl.2015.2029

Awad, G. E. A., Aty, A. A. Abd El., Shehata, A. N., Hassan, M. E., \& Elnashar, M. M. (2016) Covalent immobilization of microbial naringinase using novel thermally stable biopolymer for hydrolysis of naringin. 3 Biotech, 6, 14 https://doi.org/10.1007/s13205-015-0338-x

Berka, R. M., \& Cherry, J. R. (2006). Enzyme biotechnology. In: Ratledge, C; Kristiansen, B. (eds.), Basic Biotechnology, 2006, $3^{\text {rd }}$ edition, Cambridge University Press, Cambridge, UK, pp. 477-498.

Binod, P., Singhania, R. R., Soccol, C. R., \& Pandey, A. (2008) Industrial enzymes. In: Pandey, A; Larroche, C; Soccol, CR; Dussap, C-G (eds.). Advances in Fermentation Technology, 2008, Asiatech Publishers, New Delhi, India, pp. 291-320.

Bram, B., \& Solomons, G. L. (1965). Production of the enzyme naringinase by Aspergillus niger. Applied Microbiology, 13, 842-845.

Busto, M. D., Meza, V., Ortega, N., \& Perez-Mateos, M. (2007). Immobilization of naringinase from Aspergillus niger CECT 2088 in poly (vinyl alcohol) cryogels for the debittering of juices. Food Chemistry, 104, 1177-1182. https://doi.org/10.1016/j.foodchem.2007.01.033

Caldini, C., Bonomi, F., Pifferi, P. G., Lanzarini, G., \& Galente, Y. M., (1994) Kinetic and immobilization studies on fungal glycosidases for aroma enhancement in wine. Enzyme and Microbial Technology, 16, 286-291. https://doi.org/10.1016/0141-0229(94)90168-6

Chandler, B. V., \& Nicol, K. (1975). Some relationships of naringin: their importance in orange juice bitterness. CSIRO Food Research Quarterly, 35:7988.

Chen, D., Niu, T., \& Cai, H. 2010. Optimizing culture medium for debittering constitutive enzyme naringinase production by Aspergillus oryzae JMU316.

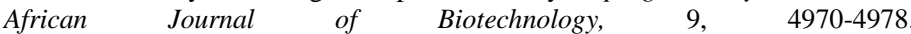
https://doi.org/10.5897/AJB10.087

Chen, Y., Zheng, R., Jia, Z., \& Ju, Y. (1990). Flavonoids as superoxide scavengers and antioxidants. Free Radical Biology \& Medicine, 9, 19-21. https://doi.org/10.1016/0891-5849(90)90045-K

Falch, E. A. (1991). Industrial enzymes - Developments in production and application. Biotechnology Advances, 9, 643-658. https://doi.org/10.1016/07349750(91)90736-F

Fernandes, P. (2010) Enzymes in sugar industries. In: Panesar, P., Marwaha, S S., Chopra, H. K. (eds.) Enzymes in Food Processing: Fundamentals and Potential Applications. 2010, I.K. International Publishing House, New Delhi, India, pp. 165-197.

Gallego, M., Pinaga, F., Ramon, D., \& Valles, S. (2001) Purification and characterization of an $\alpha$-L-rhamnosidase from Aspergillus terreus of interest in winemaking. Journal of Food Science, 66, 204-209. https://doi.org/10.1111/j.1365-2621.2001.tb11317.x

González-Vázquez, R., Azaola-Espinosa, A., Osorio-Revilla, G., GallardoVelazquez, T., Cruz-Victoria, T., Arana-Errasquin, R., \& Rivera-Espinoza, Y. (2011). The effect of different carbon sources and salts in the production of naringinase by Aspegillus niger ATCC1015. Revista Mexicana de Ingeniería Química. 10, 1-8.

Habelt, K., \& Pittner, F. (1980). A rapid method for the determination of naringin, prunin, and naringenin applied to the assay of naringinase. Analytical Biochemistry, 134, 393-397. https://doi.org/10.1016/0003-2697(83)90314-7

Hagedorn, S. \& Kaphammer, B. (1994). Microbial catalysis in the generation of flavour and fragrance chemicals. Annual Review of Microbiology, 48, 773-800. https://doi.org/10.1146/annurev.mi.48.100194.004013

Hasan, F., Shah, A. A., \& Hameed, A. (2006). Industrial applications of microbial lipases. Enzyme and Microbial Technology, 39, 235-251. https://doi.org/10.1016/j.enzmictec.2005.10.016

Hashimoto, W., Miyake, O., Nankai, H., \& Murata, K. (2003). Molecular identification of an $\alpha$-L-rhamnosidase from Bacillus sp. Strain GL1 as an enzyme involved in complete metabolism of gellan. Archives of Biochemistry and Biophysics, 415, 235-244. https://doi.org/10.1016/S0003-9861(03)00231-5 Illanes, A. (2008). Introduction. In; Illanes A. (ed.) Enzyme Biocatalysis. Principles and Applications. Springer, pp.19-56. 
Kaur, A., Singh, S., Singh, R. S., Schwarz, W. H. \& Puri, M. (2010). Hydrolysis of citrus peel naringin by recombinant $\alpha$-1-rhamnosidase from Clostridium stercorarium. Journal of Chemical Technology and Biotechnology, 85, 14191422. http://doi.org/10.1002/jctb. 2433

Kirk, O., Borchert, T. V., \& Fuglsang, C. C. (2002). Industrial enzyme applications. Current Opinion in Biotechnology, 13, 345-351. https://doi.org/10.1016/S0958-1669(02)00328-2

Konno, A., Misaki, M., Toda, J., Wada, T., \& Yasumatsu, K. (1982). Bitterness reduction of naringin and limonin by $\beta$-cyclodextrin. Agricultural and Biological Chemistry, 46, 2203-2208. https://doi.org/10.1080/00021369.1982.10865423

Kumar, A., Singh, M. K., \& Amena, S. (2015). Optimization of naringinase production and its purification from Micrococcus sp. International Journal of Pharmacy and Pharmaceutical Sciences, 7, 269-272.

Manzanares, P., Hetty, C., Broeck, V., Leo, H., de Graff, L. H., Visser, J. (2001) Purification and characterization of two different $\alpha$-L- rhamnosidases RhaA and RhaB from A. aculeatus. Applied and Environmental Microbiology, 67, 2230 2234. https://doi:10.1128/AEM.67.5.2230-2234.2001

Mendoza-Cal, A., Cuevas-Glory, L., Lizama-Uc, G., \& Ortiz-Vázquez, E. (2010). Naringinase production from filamentous fungi using grapefruit rind in solid state fermentation. African Journal of Microbiology Research, 4, 1964 1969.

Miguel, Â. S. M., Martins-Meyer, T. S., Figueiredo, É. V. da Costa, Lobo, B. W. P., \& Dellamora-Ortiz, G. M. (2013). Enzymes in bakery: Current and future trends, In: Food Industry, Muzzalupo, I. (Ed.), ISBN: 978-953-51-0911-2, InTech, pp 287-321.

Norouzian, D., Hosseinzadeh, A., Nouri Inanlou, D., \& Moazami, N. (2000). Production and partial purification of naringinase by Penicillium decumbens PTCC 5248. World Journal of Microbiology and Biotechnology, 16, 471-473. https://doi.org/10.1023/A:1008962131271

Olsen, R. W., \& Hill, E. C. (1964). Debittering of concentrated grapefruit juice with naringinase. Proceedings of Florida State Horticultural Society, 77, 321 325 .

Olson, A. C., Gray, G. M., \& Guadagni, D. G. (1979). Naringin bitterness of grape fruit juice debittered with naringinase immobilized in a hollow fiber Journal of Food Science, 44, 1358-1361. https://doi.org/10.1111/j.13652621.1979.tb06438.x

Patil, M. B., \& Dhake, A. B. (2014). Debittering of citrus fruit juice by naringinase of Penicillium purpurogenum. International Journal of Engineering Science and Research Technology. 3, 266-270.

Pavithra, M., Prasanna, D. B., \& Saidutta, M. B. (2012). Production of naringinase by a new soil isolate of Serratia sp.: effect of different carbon and nitrogen sources. Research Journal of Biotechnology, 7, 208-211.

Petersen, S. B. (2005). Protein engineering: Design and engineering on the nano scale. In: Straathof, A. J. J., \& Adlercreutz, P. (eds.) Applied Biocatalysis, 2nd ed Amsterdam: Harwood Academic Publications. pp 263-310.

Poulsen, P. B., \& Buchholz, K. (2003). History of enzymology with emphasis on food production. In: Whitaker, J. R., Voragen, A. G. J., \& Wong, D. W. S. (eds.), Handbook of food enzymology. ISBN 9780824706869, CRC- Press (Taylor \& Francis Group), New York.

Puri, M., \& Banerjee, U. C. (2000). Production, purification, and characterization of the debittering enzyme naringinase. Biotechnology Advances, 18, 207-217. https://doi.org/10.1016/S0734-9750(00)00034-3

Puri, M., \& Kalra, S. (2005). Purification and characterization of naringinase from a newly isolated strain of Aspergillus niger 1344 for the transformation of flavonoids. World Journal of Microbiology and Biotechnology, 21, 753-758. https://doi.org/10.1007/s11274-004-5488-7

Puri, M., Banerjee, A., \& Banerjee, U. C. (2005). Optimization of proces parameters for the production of naringinase by Aspergillus niger MTCC 1344 Process Biochemistry, 40, 195-201. http://doi.org/10.1016/j.procbio.2003.12.009 Puri, M., Kaur, A., \& Singh, R. S. (2010a). Response surface optimization of medium components for naringinase production from Staphylococcus xylosus MAK2. Applied Biochemistry and Biotechnol, 162, 181-191. http://doi.org/10.1007/s12010-009-8765-y

Puri, M., Kaur, A., Barrow, C. J. \& Singh, R. S. (2011). Citrus peel influences the production of an extracellular naringinase by Staphylococcus xylosus MAK2 in a stirred tank reactor. Applied Microbiology and Biotechnology, 89, 715-722. http://doi.org/10.1007/s00253-010-2897-4

Puri, M., Kaur, A., Kanwar, J. R., Singh, R. S. (2008). Immobilized enzymes for debittering citrus fruit juices, In: Busto, M. D., \& Ortega, N. (Eds.) Food Enzymes: Application of New Technologies, Transworld Research Network, India, pp. 91-103.

Puri, M., Kaur, A., Singh, R. S., Schwarz, W. H., Kaur, A. (2010b). One-step purification and immobilization of his-tagged rhamnosidase for naringin hydrolysis. Process Biochemistry.45, 451-456. https://doi.org/10.1016/i.procbio.2009.11.001

Puri, M., Marwaha, S. S., Kothari, R. M., \& Kennedy, J. S. (1996). Biochemical basis of bitterness in citrus fruit juices and biological approaches for debittering. Critical Reviews in Biotechnology, 16, 145-155 https://doi.org/10.3109/07388559609147419
Radhakrishnan, I., Sampath, S., \& Kumar, S. T. (2013). Isolation and characterization of enzyme naringinase from Aspergillus flavus. International Journal of Advanced Biotechnology and Research. 4, 208-212.

Sahota, P. P., \& Kaur, N. (2015). Characterization of enzyme naringinase and the production of debittered low alcoholic kinnow (Citrus raticulata blanco) beverage. International Journal of Advanced Research. 3, 1220-1233.

Saranya, D., Shanmugam, S., Kumar, S. T., Thayumanavan, B., \& Rajasekaran, P. (2009). Purification and characterization of naringinase from Candida tropicalis. Advanced Biotechnology. 9, 11-13.

Singh, R. S., \& Yadav, M. (2012). Biochemical and molecular characterization of a new aspartase producer Aeromonas media NFB-5 from effluent of a fertilizer factory. Current Biotechnology, 1, 185-193. https://doi.org/10.2174/2211550111201030185

Soares, I., Távora, Z., Barcelos, R. P., \& Baroni, S. (2012). Microorganismproduced enzymes in the food industry, scientific, health and social aspects of the food industry. Valdez, B. (Ed.), ISBN: 978-953-307-916-5.

Thammawat, K., Pongtanya, P., Juntharasri, V., \& Wongvithoonyaporn, P. (2008). Isolation, preliminary enzyme characterization and optimization of culture parameters for production of naringinase isolated from Aspergillus niger bcc 25166. Kasetsart Journal (Natural Science) 42, 61-72.

van Oort, M. (2010). Enzymes in food technology - introduction. In: Whitehurst R. J., \& van Oort, M. (eds.) Enzymes in Food Technology, second ed. Chichester: Wiley-Blackwell. p. 1-17

Xu, H., Wei, P., Zhou, H., Fan, W., \& Ouyang, P. (2003). Efficient production of L-phenylalanine catalyzed by a coupled enzymatic system of transaminase and aspartase. Enzyme and Microbial Technology, 33, 537-543. https://doi.org/10.1016/S0141-0229(03)00206-0

Yadav, M., Sehrawat, N., Sangwan, A. (2014). Mechanism of action of key industrial enzymes. In: Beniwal, V., \& Sharma, A. K. (eds.) Industrial Enzymes. Trends, Scope and Relevance. pp 1-13. Nova Publishers, New York, USA, ISBN: 978-1-63321-343-2

Yadav, S., \& Yadav, K. D. S. (2000). Secretion of $\alpha$-L-rhamnosidase by Aspergillus terreus and its role in debittering of orange juice. Journal of Scientific \& Industrial Research, 59, 1032-1037.

Yanai, T., \& Sato, M. (2000). Purification and characterization of an alpha-Lrhamnosidase from Pichia angusta X349. Bioscience, Biotechnology and Biochemistry, 64, 2179-2185. https://doi.org/10.1271/bbb.64.2179

Zhu, Y., Jia, H., Xi, M., Xu, L., Wu, S., \& Li, X. (2017). Purification and characterization of a naringinase from a newly isolated strain of Bacillus amyloliquefaciens 11568 suitable for the transformation of flavonoids. Food Chemistry, 214, 39-46. https://doi.org/10.1016/j.foodchem.2016.06.108

Zverlov, V., Hertel, C., Bronnernmeier, K., Hroch, A., Kellermann, J., \& Schwarz, W. H. (2000). The thermostable alpha-L-rhamnosidase RamA of Clostridium stercorarium: biochemical characterization and primary structure of a bacterial alpha-L-rhamnoside hydrolase, a new type of inverting glycoside hydrolase. Molecular Microbiology, 35, 173-179. https://doi.org/10.1046/j.13652958.2000.01691.x 